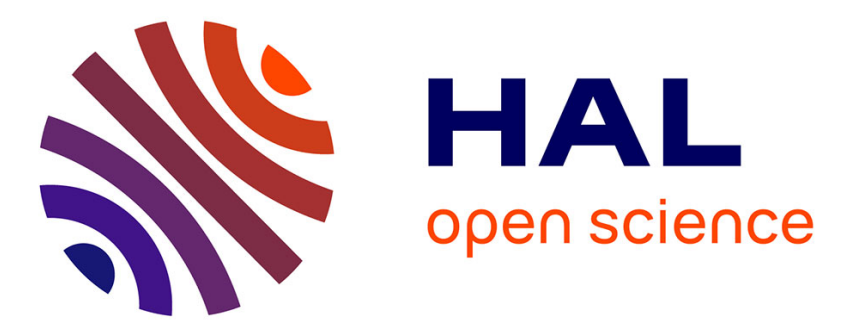

\title{
Impact of farming systems on agricultural landscapes and biodiversity: from plot to farm and landscape scales
}

Gilles Martel, Stéphanie Aviron, Alexandre Joannon, Etienne Lalechère, Bénédicte Roche, Hugues Boussard

\section{- To cite this version:}

Gilles Martel, Stéphanie Aviron, Alexandre Joannon, Etienne Lalechère, Bénédicte Roche, et al.. Impact of farming systems on agricultural landscapes and biodiversity: from plot to farm and landscape scales. European Journal of Agronomy, 2019, 107, pp.53-62. 10.1016/j.eja.2017.07.014 . hal01588617

\section{HAL Id: hal-01588617 https://hal.science/hal-01588617}

Submitted on 22 Oct 2021

HAL is a multi-disciplinary open access archive for the deposit and dissemination of scientific research documents, whether they are published or not. The documents may come from teaching and research institutions in France or abroad, or from public or private research centers.

$$
\text { Copyright }
$$

L'archive ouverte pluridisciplinaire HAL, est destinée au dépôt et à la diffusion de documents scientifiques de niveau recherche, publiés ou non, émanant des établissements d'enseignement et de recherche français ou étrangers, des laboratoires publics ou privés. 


\section{Impact of farming systems on agricultural landscapes and biodiversity: from plot}

\section{to farm and landscape scales.}

Gilles Martel $^{ \pm 1}$, Stéphanie Aviron ${ }^{1}$, Alexandre Joannon ${ }^{1}$, Etienne Lalechère ${ }^{1 *}$, Bénédicte Roche ${ }^{1}$, Hugues Boussard 1

1 INRA UMR0980 BAGAP, 65 rue de Saint Brieuc, 35042 RENNES Cedex, France

* Present address: Irstea - Lisc, 63178 Aubière - France

士Corresponding author: gilles.martel@inra.fr 

farm and landscape scales.

3

\section{Abstract}

Green-way policies in agricultural landscapes focus on ecological continuity between semi-natural elements (hedgerows, permanent grasslands, woods) and landscape heterogeneity. These policies suggest annual crops and temporary grasslands exhibit a negative or neutral impact on biodiversity. However, recent studies indicated the spatial continuities between different crops (spring vs. winter) showed positive impacts on biodiversity. These landscape patterns were directly related to farmers' decisions regarding the crops cultivated and where the crops were distributed spatially on the farm. The aim of the present study was to evaluate the impacts of different livestock farming system management types on crop patterns and associated biodiversity (carabid beetles) in agricultural landscapes. We combined empirical analyses of farmers' decision making and ecological data to develop a modeling framework simulating crop allocation and abundance of two different carabid beetle species groups (maize and woody species). Modeling included field, farm, and landscape levels. We simulated different scenarios, where two livestock farming systems, swine and dairy, were combined in different proportions (i.e. number of swine vs. dairy farms) in two agricultural landscapes with varied hedgerow densities. Simulations showed maize carabid species abundance was higher in swine production landscapes due to more frequent spatial continuities between spring and winter crops. In contrast, woody carabid species were more abundant in mixed landscapes (dairy and swine) under high crop diversity. For a given combination of livestock farming systems, simulated landscapes were highly variable in crop acreages and spatial continuities between crops. Our results emphasized the need to manage landscape at a collective level, where crop allocation decisions create more interfaces without modifying livestock farming system combinations.

Keywords: Agricultural landscape modeling, Biodiversity, Carabid beetle, Livestock, Heterogeneity, Mixed landscape 


\section{Introduction}

Preventing further biodiversity losses in agricultural landscapes is an important social and economic issue, particularly due to societal expectations regarding the provision of ecosystem services, such as pollination and pest regulation from species at risk, e.g. Apis mellifera, Rodolia cardinalis (Kleijn and Sutherland, 2003; Le Roux et al., 2008; Millennium Ecosystem Assessment, 2005). Among the major causes responsible for the decline in biodiversity, habitat fragmentation (corresponding to a reduction in suitable species habitat and increased habitat isolation; Fahrig, 2003) was inarguably identified as a main driver in species extinction (Fahrig, 2003; Krauss et al., 2010; Tilman et al., 2001). The connectivity of remaining suitable habitat fragments - defined as the degree to which the landscape facilitates or impedes species movements (Taylor et al., 1993) is therefore considered particularly critical for species survival (Fahrig and Merriam, 1985, 1994; Moilanen and Hanski, 1998; Ricketts, 2001).

A variety of green-way policies have been developed and implemented in Europe and elsewhere to promote habitat connectivity in agricultural landscapes through the design of "ecological networks" (Bennett and Mulongoy, 2006). Existing policies primarily focus on the connectivity of seminatural habitats (hedgerows, permanent grasslands, woods) (e.g. the Natura 2000 network in the EU), which was found crucial for many species survival (Bianchi et al., 2006; Billeter et al., 2008). Under these policies, the "matrix" composed of annual crops and temporary grasslands was expected to result in a negative or neutral impact on biodiversity. Some studies suggested the presence of annual crops with dense cover had a positive impact on woody species (see e.g. Fitzgibbon, 1997; Ouin et al., 2000). The connectivity of annual crops, which serve a role for species using cropped habitats during their life cycle was also reported, such as pollinators or natural enemies of crop pests (Burel et al., 2013; Maisonhaute, 2010; Varchola and Dunn, 1999; Vasseur et al., 2013). Because biotic and abiotic resources are ephemeral in annual crops, the survival of these species is expected to depend on their ability to colonise new suitable habitats to supplement or complement resources (Dunning et al., 1992). The temporal connectivity of crops, 
such as winter and spring crops, which offer resources at asynchronous periods, might guarantee supplementation and complementation processes and therefore native species survival (Burel et al., 2013; Vasseur et al., 2013).

Papy (2001) showed annual crop connectivity in agricultural landscapes was directly related to farmers' decisions regarding the crops cultivated and where the crops were geographically located on the farm. In livestock farms, crop choice was associated with animal feeding management (Papy, 2001). When several animal types were bred and include a dairy herd, the main objective was to produce fodder (i.e. primarily grass and maize) for dairy animals (Garcia et al., 2005). In dairy farms, the diet composition and field spatial organization (distance of fields to farmstead) influenced crop rotation choices (Brunschwig et al., 2006). The main factor determining crop rotation on swine farms was the presence of a feed production facility on the farm (Tersiguel et al., 2012). Tersiguel et al. (2012) reported swine farms grow primarily wheat and maize when feed production facilities were on the farm, whereas swine farms without feed production facilities grow a large diversity of winter crops and less maize. In addition to feed production, crop market prices (Reganold et al., 2011) and manure management (Ramonet et al., 2014) also played a role in crop rotation choices for all farming systems. Crop location on the farm depended on field characteristics, crop management requirements, and distance between field and facilities (Brunschwig et al., 2006; Maxime et al., 1995). The types and diversity of livestock farming systems associated with the field pattern and characteristics on farms might therefore be important drivers of crop surface area and spatial configuration, i.e. crop connectivity. However, to our knowledge, studies have not yet attempted to associate the agronomic drivers of crop patterns on biodiversity, which might be due to the challenges in experimentation on these factors: the farming system is a specific choice of a farmer and cannot be altered. Modeling the agricultural landscape resulting from crop organization by farmers is an alternative. Several landscape models have been developed in recent years, mainly based on statistical inferences (Dury, 2011). The models are largely derived from data mining of land cover databases, where the farm level is lacking. This 
implies the models cannot integrate an explicit representation of a cropping plan decision rule at the farm level. Some models include the possibility to define several groups of fields, and for each, specific parameter are available to simulate land cover (e.g. Castellazzi et al., 2010), but for ecological analyses the models are not defined. However, a wide range of whole farm models have been developed to identify the best cropping plan to fit farmer objectives (Chardon et al., 2012; Pannell, 1996; Rotz et al., 1999; Rounsevell et al., 2003). Some of these models do not include a spatial representation of the cropping plan (e.g. Schils et al., 2007) and cannot be used to evaluate landscape configuration. However other models include a spatial representation of cropping plans, but i) produce only one optimized crop allocation at the farm level, and ii) do not allow aggregation of several farms within a landscape (e.g. Chardon et al., 2012). The role of agronomic factors should be explored by developing a model that describes the diversity of possible crop distributions within a farming system and not only an optimal model.

The objectives of this study were to evaluate the impact of different livestock farming management systems on landscape patterns related to crops and associated biodiversity using carabid beetles (Coleoptera, Carabidae) as the model species. Carabid beetles have been extensively studied in agricultural landscapes (Koivula, 2011; Kromp, 1999; Rainio and Niemelä, 2003) and they are known to respond to the effects of landscape composition or configuration related to semi-natural habitats (Billeter et al., 2008; Duflot et al., 2015; Puech et al., 2014) or land-use diversity (Ekroos et al., 2010; Maisonhaute et al., 2010). The following hypotheses were tested: i) the adoption of different livestock farming systems generated changes in landscape patterns observed in relative amounts of spring and winter crops and crop connectivity; ii) the observed changes were modulated by the spatial characteristics of farm fields; and iii) changes influenced carabid beetle species using cropped habitats, but not on species using semi-natural habitats. Our hypotheses were tested using a modeling framework, which simulated the diversity of agricultural landscapes based on crop allocation decision rules at the farm level and estimated biodiversity based on landscape 
configurations. We chose two different livestock farming systems as a case study - swine and dairy — in hedgerow network landscapes ("bocage” landscapes) of Brittany (France).

\section{Materials and Methods}

Our landscape modeling framework combined plot (crop field or woody element, here hedgerow), and its landscape context (described in a circle centred on the plot, with varying radius sizes), the landscape unit level (defined here as a 500m radius circle), the individual farm level, and the level of several farms (eight farms in total) (Figs. 1 and 2). The model combined two ecological models predicting carabid abundance at the plot level according to plot landscape context (A), a crop allocation model at farm level integrating agronomic decisions and constraints (B), and digitized maps of real landscapes including several farm territories (C) to predict and assess landscape patterns and ecological effects produced under different scenarios of farming system combinations (D and E). The combination of ecological models with farming scenario and landscape analysis simulations were conducted in APILand virtual laboratory for landscape modeling (Boussard et al., 2010). This modeling platform includes the following: i) a meta-model of landscape representation in space, time, and theme, which facilitates a non-agricultural matrix (roads, buildings, forests, and hedgerows) and farm territory combination; and ii) temporal simulation tools to combine agronomic and ecological models.

\subsection{Ecological and agronomic models}

\subsubsection{Predictive models of carabid beetle abundances: the 'maize' \& 'woody' models (A)}

Statistical modeling was performed to simulate carabid beetle abundance at the plot level (crop field or woody elements) based on the characteristics of plot landscape contexts (amount, spatial connectivity, and cultivated and uncultivated habitat heterogeneity) (see Appendix A for more details). Multi-model inference (Burnham and Anderson, 2002) applying Mixed Generalized Linear Models (GLMM) was used to link existing carabid data and landscape metrics (calculated in 
different radius sizes) in landscape case studies in Brittany, Western France (Duflot et al., 2014, 2015, 2016). Analyses were performed for two different indicator carabid species groups, i.e. species associated with woody habitats ('woody' model) and species associated with maize crops ('maize' model). The final statistical models identified for the two carabid groups (best models with the lowest Akaike's information criterion (AICc)) were the following:

$$
\text { - Maize species: } N_{\text {maize }}=e^{\left(4.98+\left(6.78^{e-04} \times E_{W I C-M A 500}\right)-\left(7.05^{e-06} \times C_{W 500}\right)\right)}
$$

where $\mathrm{N}_{\text {maize }}$ is the abundance of maize species, EWIC-MA500 is the edge length between maize and winter crops in a $500 \mathrm{~m}$ radius and $\mathrm{C}_{\mathrm{W} 500}$ is the connectivity of woody habitats in a $500 \mathrm{~m}$ radius.

$$
\text { - Woody species: } N_{\text {woody }}=e^{\left(5.43^{e-01}+\left(3.49^{e-04} \times C_{W 50}\right)+\left(6.80^{e-05} \times C_{G 50}\right)+\left(1.37 \times S H D I_{50}\right)\right)}
$$

where $\mathrm{N}_{\text {woody }}$ is the abundance of woody species, and $\mathrm{C}_{\mathrm{W} 50}, \mathrm{C}_{\mathrm{G} 50}$, and $\mathrm{SHDI}_{50}$ represent respectively woody habitats and grasslands connectivity and land-use Shannon diversity in a $50 \mathrm{~m}$ radius.

The two carabid models explained a good percentage of variation in carabid abundances (pseudo- $\mathrm{R}^{2}$ $=0.48$ for both models) (Appendix A). The predictive capacity of the two statistical models was assessed by i) calculating a measure of Root Mean Square Error of Prediction (RMSEP) with k-fold cross-validation (where $\mathrm{k}=10$ ); and ii) fitting observed and predicted values for both models. The 'maize' model had a RMSEP of 80.3 individuals, which corresponded to $33 \%$ of the median observed abundances of maize species $(\min =9$, $\max =494)$. The 'woody' model had a RMSEP of 20.5 individuals, which corresponded to $49 \%$ of the median observed abundances of woody species $(\min =0, \max =83)$. The comparison of observed and predicted abundances showed that both models tended to underestimate predicted abundances compared to observations (Figure 1, Appendix A). It also showed for both models a correct, overall fit between predicted and observed values ('maize' model: pearson correlation $\mathrm{R}=0.64$; 'woody' model: $\mathrm{R}=0.58$ ), but weaker relationships for the highest abundance values (above median values) (Figure 1, Appendix A). The two models were integrated in the APILand virtual laboratory as the 'maize' and 'woody' models. 


\subsubsection{Model of crop allocation: the CAPFarm model (B)}

A crop allocation problem solver was developed to simulate crop allocations over years at the farm level. The crop allocation problem was defined by Akplogan et al. (2013) as "a spatiotemporal planning problem in which crops are assigned to fields over a finite time horizon" and we solved the problem by assigning "crops (values) to fields (variables) over a finite time horizon" (Akplogan et al., 2013).

We developed our crop allocation problem solver - 'CAPFarm' - applying the following steps: i) the JAVA Choco3 Constraint Satisfaction Problem (CSP) solver (Prud'homme et al., 2014) was employed to build a crop allocation problem solver in the APILand platform; ii) field data from farm surveys in Brittany (Western France) were applied to conduct a first parameterization of the model integrating crop distribution constraints observed in livestock farming systems in the area investigated (constraint list in Table 1) (Roche et al., 2013); two farms with different crop rotations and location rules were considered at this stage, i.e. a swine farming system ('swine') and a dairy farming system ('dairy'); and iii) crop allocation simulations were run for the two farms to generate maps of possible crop allocation during five consecutive years on surveyed farms; the maps were verified by farmers to modify and/or validate crop rotation and location rules.

The final model parameterization integrated the following rules: i) the 'swine' system was characterized by large geographic surface areas cultivating cereals (including rape seed), no temporary grassland, short crop rotations, and only 50\% usable agricultural area (UAA) required for the minimum cropped area; and (ii) the 'dairy' system was characterized by distance from pasture fields to milking area (farmstead) constraints, large geographic surface areas cultivating temporary grassland and maize for forage self-sufficiency, long crop rotations including cereal crops, and 90\% of the UAA required for minimum cropped area. The final set of rules for each case system is shown in Table 1.

\subsection{Selection of case study sites: the 'open' \& 'dense' landscape units (C)}


We tested the sensitivity of our simulation results to "bocage" characteristics by selecting two landscape units (and their associated farms) with different densities of woody elements. The landscape units were defined within $500 \mathrm{~m}$ radii circles to run both ecological model simulations (see part 2.1). We used two existing GIS databases to produce maps with realistic landscape composition and configuration regarding arable fields, roads, buildings, and woody elements: i) a regional map of woody elements (hedgerows and woodlots) produced by the CNRS-LETG laboratory (Hubert-Moy et al., 2012); ii) the land parcel identification system (LPIS), where farm territories and arable islets are mapped. Moving window analyses were applied to these maps using the Chloe2012 software (Boussard and Baudry, 2014) to select two landscape units with varied densities of woody elements, but with a similar number of farms (eight) and UAA percentage (90\% of the circle areas). Finally, we digitized fields within LPIS islets and identified a farmstead for each farm added from aerial photographs and satellite images. This resulted in production of two divergent virtual landscape units based on real landscape composition and configuration: an 'open' landscape unit with very low density of woody elements $(0.5 \%$ of the $500 \mathrm{~m}$ radius circle area) and a 'dense' landscape unit, with higher density of woody elements $(16.3 \%$ of the $500 \mathrm{~m}$ radius circle area). The farms composing those landscape units are noted $\mathrm{O} 1$ to $\mathrm{O} 8$ for open landscape unit and F1 to F8 for dense landscape unit.

\subsection{Virtual experiment plan for landscape and ecological simulations (D)}

The effects of crop allocation on carabid abundance was defined by simulating the following virtual experiment plan applied to the two case study landscape units (open and dense):

- At the farm level and for each of the eight farms, which composed each landscape unit, we presimulated crop allocation for both farming systems, i.e. 'swine' and 'dairy' using the CAPFarm solver parameterized with validated sets of agronomic constraints (B). One thousand simulation iterations were run to obtain several crop allocation over 10 years for each farm and each farming system. Due to variable constraint levels resulting of the combination farm / farming 
system, we obtained from 9 to 810 successes over the 1000 iterations. These successful iterations allowed the generation of various possible crop distribution patterns regarding each set of agronomic constraints.

- At the all farms level, we simulated 256 scenarios representing all combination possibilities of two farming systems across eight farms (from zero to eight farms in swine vs. dairy farming). For each scenario, 250 simulation iterations were performed to ensure sufficient robustness in the modeling results and allow sufficient comparisons among scenarios. Simulations were conducted by randomly selecting one of the pre-simulated crop allocations for each farm over 10 years. This resulted in the production of $10 \times 250 \times 256$ simulated landscape maps for each landscape unit. These sets of simulated landscape maps are henceforth referred to as 'open landscape' or 'dense landscape'.

- At the plot level, the 'maize' and 'woody' models were run using landscape metrics calculated on simulated landscape units to predict carabid abundances at the plot level based on its landscape context. For the 'maize' model, landscape metrics were calculated within a $500 \mathrm{~m}$ radius around the central arable field of each landscape unit. Calculations were conducted only for years where these central fields were cultivated as maize according to crop allocation model simulations. The 'woody' model had a limited spatial extent $(50 \mathrm{~m})$ used in the metric calculations. Therefore, running the simulations for a central woody element (hedge) at each landscape unit could not ensure sufficient variability for plots' spatial context among scenarios. Subsequently, the 'woody' model was run on each year for several woody elements based on the density of woody elements at each landscape unit (five at the 'open' landscape unit and 29 at the 'dense' landscape unit).

\subsection{Data analyses (E)}

As agronomic rules contains some time dependencies (i.e.: crop return time), not all the rules are effective at the start of the simulation. The first five years (over the ten simulated) were therefore as an initialization and stabilization phase and were excluded from analyses. On the remaining five 
years, we considered each year of a simulated landscape unit as a statistical individual. This resulted in 1250 statistical individuals (i.e. simulated landscapes-year) for each scenario.

We analysed the variation in cultivated area amongst scenarios, by calculating the surface area of crops (averaged over the 1250 simulated landscapes-year) at the all farms and landscape unit levels. We distinguished three categories of crops: (i) winter crops (WIC) grouping wheat, oil seed rape and barley, (ii) spring crops (SC) grouping maize-corn and maize-silage and (iii) grassland (GL) grouping permanent and temporary grassland, pasture and lucerne.

The impacts of farming systems scenarios on carabid abundance predicted by 'maize' and 'woody' models at the plot level were analyzed by testing the effects of the following two variables: i) number of farms under dairy production (0 to 8 farms); and ii) percentage of geographic surface area in each landscape unit managed under dairy production (see part 2.3.).

In a last step, we analyzed farm contributions to variation in carabid beetle abundance predicted by the 'maize' model using a specific analysis. We focused on the 'maize' model, as only one calculation was required per simulated landscape, in contrast to the 'woody' model (see part 2.3.). Focusing on the 'maize' model allowed us to limit the potential factor number able to modify the farm contributions to variation in carabid abundance predicted by ecological models. The contribution of an individual farm $i$ to the variation in predicted abundances of maize carabids was assessed in several steps. First, the 256 initial scenarios were split into 128 sets of two modalities, where for each set, the individual farm $i$ was either under swine farming ('S') or dairy farming ('D'), whilst the other seven farms had fixed farming type. The 128 sets corresponded to the whole possibilities regarding the type of farming system attributed to each of the other seven farms (as explained in section 2.3). For instance, the following are three sets created to calculate the contribution to the variation in predicted abundances of maize carabids of farm \#1: $\{\underline{\mathbf{S} D D D D D D D}$; $\underline{\mathbf{D} D D D D D D D}\},\{\underline{\mathbf{S} D D D D D D S} ; \underline{\mathbf{D} D D D D D D S}\},\{\underline{\mathbf{S} D D D D D S D} ; \underline{\mathbf{D} D D D D D S D}\}$ (where each letter represents an individual farm). In a second step, we noted $\mathrm{N}[\mathrm{S}]_{\mathrm{x}}$ the simulated abundance of maize carabid beetles for the set $\mathrm{x}$ with the swine modality and $\mathrm{N}[\mathrm{D}]_{\mathrm{x}}$ for the dairy modality. The 
contribution Cset $\mathrm{x}_{\mathrm{x}}$ of the farm $i$ to the variation in carabid abundances for one set $\mathrm{x}$ was estimated as Cset $_{\mathrm{x}}=\mathrm{N}[\mathrm{S}]_{\mathrm{x}}-\mathrm{N}[\mathrm{D}]_{\mathrm{x}}$. The final contribution of farm $i, \mathrm{C} i$ was the average contribution of all sets $\mathrm{x}$ : $\mathrm{C} i=\frac{1}{128} \sum_{\mathrm{x}=1}^{128}\left(N[S]_{x}-N[D]_{x}\right)$

Because maize carabid abundances are related to edge length between winter and spring crops we calculated several descriptors of farm characteristics within the landscape units to explain their contribution to variation in carabid abundances (Table 2): i) the geographical area, ii) the total edge length, with the hypothesis that farm contribution is high when the total edge length of the farm in the landscape unit is high, and iii) grassland area (from minimum to maximum obtained within replications) with the hypothesis that the contribution of a farm will be high if it has large grassland areas when it is under dairy farming (since it will result in a large decrease of winter crop area when changing from swine to dairy production).

\section{Results}

\subsection{Effect of farming systems on cropping plan}

Differences in crop surface areas (averaged over the 1250 landscapes-year) at the all farms scale based on percentage of all farms geographic surface area under dairy farming in both landscape units is shown in Figure 3. In each landscape unit, the transition from swine production to dairy production resulted in the same trend: a decrease in winter crop areas and increase in grasslands areas. Dense and open landscape units differed in grassland areas in the swine farm scenario only $(0$ $\%$ of area under dairy farming). This result was due to the smaller field size in the dense landscape unit, which resulted in a higher number of fields used as permanent grassland compared with the open landscape unit. Differences in grassland percentages between the two landscape units (67\% of all farm areas in both landscape units) were not observed in the dairy only scenario (100\% of area under dairy farming), the permanent grassland area was lower than the grassland area required by these systems. Consequently, the increased grassland percentage in dense landscape unit was lower 
than in the open landscape unit. Within a scenario, the variability in crop surfaces was low 285 (variation coefficient below $15 \%$ ).

Differences in each crop surface at the landscape unit level (averaged over the 1250 landscape-year) based on percentage of the geographic area managed by dairy farms (a) or number of dairy farms (b) is depicted in Figure 4. Results indicated crop differences were the same compared with the all farms scale. Variability within scenario was higher than that observed at the all farms scale. The variation coefficient for all spring crops remained high in all scenarios $(\sim 30 \%)$. Spring crops are necessary in both farming systems and no specific agronomic constraints are required on the seedlings, therefore increased variability was observed related to a scale effect. The simulated grassland percentage is correlated to the percentage of the landscape unit area managed by dairy farms but locally two scenarios with almost the same percentage of the landscape unit managed by dairy farms (i.e. 50\%) could have very different grassland percentage (i.e. from 15 to 30\%) (Fig. 4a). The differences were due to the spatial organization of farms fields and the farmstead position. Some farmsteads were within the landscape unit and so pastures were more often seeded within landscape unit. For farms with facilities outside the landscape unit, fields managed within landscape unit were more often in winter or spring crops and not grasslands. The wide range of variability in cropping plans for a fixed number of dairy or swine production farms is shown in Figure $4 \mathrm{~b}$. Differences in the farm area managed at the landscape unit and the previously explained field organization explain these observations.

\subsection{Predictions of carabid abundance in simulated landscapes}

Predicted abundance of maize and woody carabid species in both landscape units, derived from the number of dairy farms (one to eight) and the geographic surface area covered by dairy production is depicted in Figure 5.

Different responses were found between the two carabid species groups and landscape units. Woody species abundance varied non-linearly based on the number of dairy farms in both 
landscape units (polynomial regression, open landscape unit: $R^{2}=0.46$, F-statistics $=108.0, P<$ 0.001; dense landscape unit: $R^{2}=0.37$, F-statistics $=76.1, P<0.001$ ) (Fig. 5.1a). Responses were maximized for different scenarios depending on landscape, i.e. for scenarios with six to seven dairy farms (over a total of eight farms) in the open landscape unit and for scenarios with two to three dairy farms (over a total of eight farms) in the dense landscape unit. In contrast, maize species abundance decreased with increasing number of dairy farms in both landscape units (linear regression, open landscape unit: $\mathrm{R}^{2}=0.42$, F-statistics $=181.2, P<0.001$; dense landscape unit: $\mathrm{R}^{2}$ $=0.38$, F-statistics $=158.8, P<0.001$ ) (Fig. 5.1b). In scenarios where dairy farming dominated, edge length between maize and winter crops was reduced. Hedgerow length did not vary within each landscape unit, therefore decreased maize species abundance was due to decreased edge length between maize and winter crops (cf. 2.1.1.). The decreased abundance of maize species was reduced in dense compared with open landscape units, in relationships with the negative effect of the connectivity of woody elements on maize carabid species.

Results regarding the surface area covered by dairy production (Figure 5.2a and 5.2b) showed that abundances of woody species vary non-linearly according to the proportion of dairy farming in both landscape units (polynomial regression, open landscape unit: $\mathrm{R}^{2}=0.37$, F-statistics $=50.1, \mathrm{p}<0.001$; dense landscape unit: $\mathrm{R}^{2}=0.81$, F-statistics $\left.=557.8, \mathrm{p}<0.001\right)$. Regarding maize species, carabid abundances were aggregated into two distinct clusters, but without relationships with the overall variation in the proportion of surface area under dairy production in both landscape units. It suggests the influence of other factors than the only proportion of surface area under dairy farming. However, within each cluster, carabid abundances tended to decrease with the proportion of dairy farming in the landscape.

\subsection{Farm contribution to the variation in carabid abundance predicted by the 'maize' model}

The 'maize' model farm contribution varied from 0 to 50.4 in the dense landscape unit and from 0.1 to 230.1 in the open landscape unit (Table 2). In both landscape units, the highest contributions 
were associated with large areas farmed at a landscape unit. Five farms with more than 10 ha in a landscape unit were major contributors to variation in carabid abundance. However, data showed no linear relationship between farm contribution and farm area within landscape unit (see farms O4, O8 in open landscape unit and F7 in dense landscape unit). Spearman correlation coefficients indicated long lengths of variable edges (i.e. each field along the edge are cultivated) and increased grassland frequencies were correlated with high contributions (Table 3). More precisely, grassland frequency was more determinant in the open landscape and variable edge length was more determinant in the dense landscape. Thus, the results indicated O8 did not contribute despite farming 7.3 ha in an open landscape unit, O8 showed the absence of variable internal edges, and increased grassland areas were rare (see percentile p80). F7 exhibited comparable variable edge length to F5 and lower relative to F3, which explained its close contribution to F5 yet lower than F3.

\section{Discussion}

\subsection{Effects of farming systems on landscape pattern and carabid abundance}

In our study, we simulated carabid abundances in fields or woody elements using statistical modelling. The two models built had a good explicative value (pseudo $\mathrm{R}^{2}=0.48$ ) but the RMSEP analyses revealed high errors of predictions of the models. For both models, these errors were higher for the highest values of predicted abundances. The higher errors of predictions for the 'woody' model suggests that variations in predicted abundances by this model should be interpreted carefully. However, we assumed that the models remained useful for a qualitative assessment of contrasted farming and landscape pattern scenarios for the two carabid groups.

Our overall results showed abundance of the two carabid groups differed due to landscape pattern effects as a function of farming system but the two models revealed different responses. Maize carabid species experienced positive abundance influence under swine farming system dominance landscapes (i.e. a $500 \mathrm{~m}$ radius around crops). This was associated with increased winter crops 
cultivated areas in swine systems, which resulted in increased edge lengths between winter crops and spring crops. In spite of the high prediction errors $(33 \%)$ of the 'maize' model, the important contrast in the predicted abundances between the most extreme farming scenarios in the open landscape unit (about 750 individuals in the 100\% swine scenarios vs. 200 individuals in the 100\% dairy scenarios) suggested a significant effect of farming systems on maize carabid beetles in these landscapes. Vasseur et al. (2013) suggested crop spatial connectivity might be an important driver of arthropod maintenance in cultivated habitats of agricultural landscapes, as it determined the spatio-temporal continuity of resources for these species. At the local scale, Burel et al. (2013) showed carabid beetles moved between adjacent, asynchronous crops (winter and spring), which suggested spatial continuities between seasonal cultivated crops favored resource complementation processes (Dunning et al., 1992) for crop carabid species. Such processes might explain the positive edge length effects between asynchronous crops on crop carabid beetle abundance at the landscape scale observed in our study. Duflot et al. (2016) reported crop configurations decreased carabid abundance, which differed from our results. Duflot et al. (2016) examined an overall carabid beetle community in cultivated wheat fields and total, gamma biodiversity, where we investigated maize carabid species groups in cultivated maize and local, alpha biodiversity, variables, which likely explains the different results observed between our studies. Our results emphasized the importance of crop diversity and configuration in biodiversity, as reinforced by previous studies (e.g. Duflot et al., 2014).

By contrast, abundances of woody carabid species varied non-linearly according to the number of dairy farms and the proportion of area under dairy farming. Abundances of these carabid species were slightly higher in landscapes with both types of farming systems (i.e. with similar relative surface areas of spring crops, winter crops and grassland) than in landscapes with specialization of production (either towards dairy or swine production). A positive effect of land-use diversity on woody species at a fine spatial scale (i.e. in a $50 \mathrm{~m}$ radius around hedgerows) served to explain this result. Fahrig et al. (2011) provided evidence that land-use diversity reflected compositional 
landscape heterogeneity. Additional study indicated it a key driver of biodiversity in agricultural landscapes (Benton et al., 2003; Fahrig et al., 2011) and diverse land-use showed beneficial effects on carabid communities (Batáry et al., 2007; Millán de la Peña et al., 2003). However, these results should be interpreted with caution since the range of variation in predicted abundances is very low (a few individuals) and the errors of prediction of the 'woody' model are high (49\%). This underlines the difficulty to explain properly the presence and abundance of species such as woody carabid species that are often very scarce in actual agricultural landscapes.

If the effects of farming system processes seemed similar in both landscape units, results indicated the range of variation in carabid abundance across scenarios was smaller in the dense (complex) landscape relative to the open landscape. This result can be compared to the mitigation role in landscape complexity to the intensification effect on biodiversity (Tscharntke et al., 2005).

\subsection{Farm contribution to variation in predicted carabid abundances}

Our modeling design was successful in elucidating the importance of individual farm level to explain variations in abundances of maize carabid beetles in the agricultural mosaic. The variability of contribution to deviation in predicted carabid abundance among farms was related to farm size, but also to the probability to seed grassland in dairy systems and to the edge length between fields where crops were sown. Brunschwig et al. (2006) and Thenail and Baudry (2004) identified a relationship between grassland seeding in dairy systems and field distance to the farmstead. Farmstead location to evaluate farm influence on predicted carabid abundance in a defined spatial area was clearly identified in these and our study. However, databases would not provide the farmstead location due to confidentiality clauses (INSEE, 2010) which limits the possible use of such database to identify the main farms able to increase the carabid beetle abundance in a specific area. In our simulations, we controlled farmstead location and analyzed location role to farm contribution to variation in predicted carabid abundance. Farms with the farmstead close to or within the processing landscape unit exhibited higher contributions to variation than farmsteads with a greater distance to processing. Factors responsible for differences in farm contribution to 
variability between landscape units can be explained by landscape structural differences. Indeed, dense landscape unit revealed large surface areas of permanent grasslands and high hedgerow lengths, which limited the edges or interfaces between crop fields. However, these remaining interfaces between crop fields in the dense landscape unit were individually more important for the abundance of crop carabid beetle than crop fields interfaces in the open landscape unit. The interface length criterion was therefore more important at the farm level in the dense landscape compared with the open landscape.

\subsection{Implications for biodiversity management in agricultural landscapes}

Predicting species abundances in agricultural landscapes using statistical modeling has limitations due to the uncertainty of predictions of ecological models (Barry and Elith, 2006). Although our models were built using an extensive dataset, there are still additional drivers of carabid abundances that could improve the predicting ability of models. However, our results on maize carabid species suggest that some specific organization of annual crops in space, maximizing the edges between asynchronous crops, could increase the abundances of these species. Presently, green way policies focus on the conservation of existing networks of semi-natural habitats. The present study suggests that farmers might contribute to create cropped green veining for the biodiversity associated to the agricultural mosaic. Our modeling approach allowed highlighting the possible contribution of farming systems and individual farmers to generate landscape configurations that are important for crop carabid species. These landscape configurations could result of localization of asynchronous crops on juxtaposed fields by an individual farmer. If our results showed this localization is possible one year, it should be tested over several years by including a new rule in our sets. As the field interfaces are often longer with fields of other farms than within the farm due to fragmentation of farms' land, another solution would be the coordination among farmers in association with other stakeholder types. For example, a group of farmers, the mayor, and a watershed advisor reduced the risk of erosion by engaging in a dialogue regarding grass strips, storage ponds, and an intercrop 
management period (Souchère et al., 2010). For biodiversity management, this type of solution should consider crop localization, under consultation with a landscape planner. Indeed, crop spatial organization is easier to understand at a collective scale, rather than individually due to the spatial constraints at the farm scale (e.g. farmstead distance, soil quality, accessibility, among other factors). Green way policies do not include collective responses, which have to pass through different mechanisms. For example, Lucas et al. (2015) described an enhancement of collective farming and several farmers already engaged in collective cropping plans (Martin et al., 2015), which should be viewed as an opportunity to improve biodiversity at landscape scales.

\section{Conclusion}

Our multi-level and agro-ecological modeling framework facilitated the evaluation of different farming system (dairy and swine) impacts on landscape patterns and carabid beetle abundance. We showed the over-representation of swine farming resulted in an increased edge length between maize and winter cereals and consequently enhanced abundances of maize carabid beetles. Both farming systems seemed necessary to favor woody carabid beetles. Moreover, our results showed, given a set of farming systems in a landscape, variability in crop patterns and edge length between winter crops and spring crops emerged. This indicated farmers have possibilities to modify crop allocation with the objective to increase landscape patterns in relationship to biodiversity issues, while maintaining their production objectives. Therefore, we recommend the following: i) crop allocation modifications at the farm level, e.g. decrease large field size by dividing fields and increase potential interfaces, increase field accessibility to animals from the farmstead; and ii) explore modifications at a collective level, since landscape patterns result from several farmers' decisions. Currently, these solutions are not integrated in policies aiming to promote biodiversity, as green veining. 
Acknowledgements: We gratefully thank Jean-Luc Roger, Gérard Savary and Eloïse Couthouis for fieldwork, Tristan Jean-Charles for testing the crop decision model and Clarisse Amiotte for interviewing kindly farmers. We also thank Nicolas Parisey and Sylvain Poggi for their counsels to obtain the ecological models.

Funding: This work has been funded by the French Ministry of Ecology (DIVA-Agriconnect project); INRA Payote research group; and Zone Atelier

Armorique (supported by CNRS and INRA).

\section{References}

Akplogan, M., de Givry, S., Metivier, J.P., Quesnel, G., Joannon, A., Garcia, F., 2013. Solving the crop allocation problem using hard and soft constraints. Rairo-Oper. Res. 47, 151-172. doi:10.1051/ro/2013032

Barry, S., Elith, J., 2006. Error and uncertainty in habitat models. J. Appl. Ecol. 43, 413-423. doi:10.1111/j.1365-2664.2006.01136.x

Batáry, P., Báldi, A., Szél, G., Podlussány, A., Rozner, I., Erdős, S., 2007. Responses of grassland specialist and generalist beetles to management and landscape complexity: Grassland specialist and generalist beetles. Divers. Distrib. 13, 196-202. doi:10.1111/j.14724642.2006.00309.x

Bennett, G., Mulongoy, K.J., 2006. Review of experience with ecological networks, corridors and buffer zones, CBD Technical Series.

Benton, T.G., Vickery, J.A., Wilson, J.D., 2003. Farmland biodiversity: is habitat heterogeneity the key? Trends Ecol. Evol. 18, 182-188. doi:10.1016/S0169-5347(03)00011-9

Bianchi, F.J.J., Booij, C.J.., Tscharntke, T., 2006. Sustainable pest regulation in agricultural landscapes: a review on landscape composition, biodiversity and natural pest control. Proc. R. Soc. B Biol. Sci. 273, 1715-1727. doi:10.1098/rspb.2006.3530

Billeter, R., Liira, J., Bailey, D., Bugter, R., Arens, P., Augenstein, I., Aviron, S., Baudry, J., Bukacek, R., Burel, F., Cerny, M., De Blust, G., De Cock, R., Diekötter, T., Dietz, H., Dirksen, J., Dormann, C., Durka, W., Frenzel, M., Hamersky, R., Hendrickx, F., Herzog, F., Klotz, S., Koolstra, B., Lausch, A., Le Coeur, D., Maelfait, J.P., Opdam, P., Roubalova, M., Schermann, A., Schermann, N., Schmidt, T., Schweiger, O., Smulders, M.J.M., Speelmans, M., Simova, P., Verboom, J., Van Wingerden, W.K.R.E., Zobel, M., Edwards, P.J., 2008. Indicators for biodiversity in agricultural landscapes: a pan-European study: Biodiversity in European Agro-ecosystems. J. Appl. Ecol. 45, 141-150. doi:10.1111/j.13652664.2007.01393.x

Boussard, H., Baudry, J., 2014. Chloe2012 : a software for landscape pattern analysis. INRA, Rennes, France.

Boussard, H., Martel, G., Vasseur, C., 2010. Spatial links specifications in the APILand simulation approach: an application to the coupling of a farm model and a carabid population model. LandMod 2010 Int. Conf. Integr. Landsc. Model. (11p).

Brunschwig, G., Josien, E., Bernhard, C., 2006. Contraintes géographiques et modes d'utilisation des parcelles en élevage bovin laitier et allaitant. Fourrages 185, 83-95.

Burel, F., Aviron, S., Baudry, J., Le Feon, V., Vasseur, C., 2013. The Structure and Dynamics of Agricultural Landscapes as Drivers of Biodiversity, in: Bojie, F., K. Bruce Jones (Eds.), Landscape Ecology for Sustainable Environment and Culture. Springer, pp. 285-308.

Burnham, K.P., Anderson, D.R. (Eds.), 2002. Model selection and multimodel inference: a practical information-theoretic approach, second edition. New-York.

Castellazzi, M.S., Matthews, J., Angevin, F., Sausse, C., Wood, G.A., Burgess, P.J., Brown, I., Conrad, K.F., Perry, J.N., 2010. Simulation scenarios of spatio-temporal arrangement of crops at the landscape scale. Environ. Model. Softw. 25, 1881-1889. doi:10.1016/j.envsoft.2010.04.006 
Chardon, X., Rigolot, C., Baratte, C., Espagnol, S., Raison, C., Martin-Clouaire, R., Rellier, J.-P., Le Gall, A., Dourmad, J.Y., Piquemal, B., Leterme, P., Paillat, J.M., Delaby, L., Garcia, F., Peyraud, J.L., Poupa, J.C., Morvan, T., Faverdin, P., 2012. MELODIE: a whole-farm model to study the dynamics of nutrients in dairy and pig farms with crops. animal 6, 1711-1721. doi:10.1017/S1751731112000687

Duflot, R., Aviron, S., Ernoult, A., Fahrig, L., Burel, F., 2015. Reconsidering the role of 'seminatural habitat' in agricultural landscape biodiversity. Ecol. Res. 30, 75-83.

Duflot, R., Ernoult, A., Burel, F., Aviron, S., 2016. Landscape level processes driving carabid crop communities in dynamic farmlands. Popul. Ecol. 58, 265-275.

Duflot, R., Georges, R., Ernoult, A., Aviron, S., Burel, F., 2014. Landscape heterogeneity as an ecological filter of species traits. Acta Oecologica 56, 19-26. doi:http://dx.doi.org/10.1016/j.actao.2014.01.004

Dunning, J.-B., Danielson, B.-J., Pulliam, H.-R., 1992. Ecological processes that affect populations in complex landscapes. Oikos 65, 169-175.

Ekroos, J., Hyvönen, T., Tiainen, J., Tiira, M., 2010. Responses in plant and carabid communities to farming practises in boreal landscapes. Agric. Ecosyst. Environ. 135, 288-293.

Fahrig, L., 2003. Effects of habitat fragmentation on biodiversity. Annu. Rev. Ecol. Evol. Syst. 34, 487-515.

Fahrig, L., Baudry, J., Brotons, L., Burel, F.G., Crist, T.O., Fuller, R.J., Sirami, C., Siriwardena, G.M., Martin, J.-L., 2011. Functional landscape heterogeneity and animal biodiversity in agricultural landscapes: Heterogeneity and biodiversity. Ecol. Lett. 14, 101-112. doi:10.1111/j.1461-0248.2010.01559.x

Fahrig, L., Merriam, G., 1994. Conservation of fragmented populations. Conserv. Biol. 8, 50-59.

Fahrig, L., Merriam, G., 1985. Habitat patch connectivity and population survival. Ecology 66, 1762-1768.

Fitzgibbon, C.D., 1997. Small mammals in farm woodlands : The effects of habitat, isolation and surrounding land-use patterns. J. Appl. Ecol. 34, 530-539.

Garcia, F., Faverdin, P., Delaby, L., Peyraud, J.L., 2005. Tournesol: un modèle pour simuler les assolements en exploitation bovine laitière. Rencontres Autour Rech. Sur Rumin. 195-198.

Hubert-Moy, L., Nabucet, J., Vannier, C., Lefebvre, A., 2012. Mapping ecological continuities: which data for which territorial level? Application to the forest and hedge network. Int. J. Geomat. Spat. Anal. 22, 619-640.

INSEE, 2010. Guide du secret statistique. INSEE, Paris (FRA).

Kleijn, D., Sutherland, W.J., 2003. How effective are European agri-environment schemes in conserving and promoting biodiversity. J. Appl. Ecol. 40, 947-969.

Koivula, M.J., 2011. Useful model organisms, indicators, or both? Ground beetles (Coleoptera, Carabidae) reflecting environmental conditions. ZooKeys 287-317.

Krauss, J., Bommarco, R., Guardiola, M., Heikkinen, R.K., Helm, A., Kuussaari, M., Lindborg, R., Öckinger, E., Pärtel, M., Pino, J., Pöyry, J., Raatikainen, K.M., Sang, A., Stefanescu, C., Teder, T., Zobel, M., Steffan-Dewenter, I., 2010. Habitat fragmentation causes immediate and time delayed biodiversity loss at different trophic levels. Ecol. Lett. 13, 597-605.

Kromp, B., 1999. Carabid beetles in sustainable agriculture: a review on pest control efficacy, cultivation impacts and enhancement. Agric. Ecosyst. Environ. 74, 187-228.

Le Roux, X., Barbault, R., Baudry, J., Burel, F., Doussan, I., Garnier, E., Herzog, F., Lavorel, S., Lifran, R., Roger-Estrade, J., Sarthou, J.P., Trommetter, M., 2008. Agriculture et biodiversité. Valoriser les synergies, Rapport INRA Expertise scientifique collective. France.

Maisonhaute, J.-E., 2010. Influence de la structure du paysage sur l'assemblage des prédateurs terricoles dans les zones agricoles non cultivées. 100pp

Maisonhaute, J.-É., Peres-Neto, P., Lucas, É., 2010. Influence of agronomic practices, local environment and landscape structure on predatory beetle assemblage. Agric. Ecosyst. Environ. 139, 500-507. 
Martin, G., Moraine, M., Ryschawy, J., Magne, M.-A., Sarthou, J.-P., Duru, M., Therond, O., 2015. Coll-ICLS: a participatory tool to support crop-livestock integration among farms. Presented at the 5th International Symposium for Farming Systems Design, Montpellier (FRA), pp. 207-208.

Maxime, F., Mollet, J.-M., Papy, F., 1995. Aide au raisonnement de l'assolement en grande culture. Cah. Agric. 4, 351-362.

Millán de la Peña, N., Butet, A., Delettre, Y., Morant, P., Burel, F., 2003. Landscape context and carabid beetles (Coleoptera: Carabidae) communities of hedgerows in western France. Agric. Ecosyst. Environ. 94, 59-72. doi:10.1016/S0167-8809(02)00012-9

Millennium Ecosystem Assessment, 2005. Ecosystems and human well-being. Island Press Washington, DC.

Moilanen, A., Hanski, I., 1998. Metapopulation dynamics: effect of habitat quality and landscape structure. Ecology 79, 2503-2515.

Ouin, A., Paillat, G., Butet, A., Burel, F., 2000. Spatial dynamics of wood mouse (Apodemus sylvaticus) in an agricultural landscape under intensive use in the Mont Saint Michel bay (France). Agric. Ecosyst. Environ. 78, 159-165.

Pannell, D.J., 1996. Lessons from a decade of whole-farm modeling in Western Australia. Rev. Agric. Econ. 18, 373-383.

Papy, F., 2001. Interdépendance des systèmes de culture dans l'exploitation agricole, in: Modélisation des agroécosystèmes et aide à la décision, 2001, Malézieux E., Trébuil G., Jaeger M. (eds)., Editions CIRAD-INRA, collection Repères (51-74)

Prud'homme, C., Fages, J.-G., Lorca, X., 2014. Choco3 Documentation.

Puech, C., Baudry, J., Joannon, A., Poggi, S., Aviron, S., 2014. Organic vs. conventional farming dichotomy: Does it make sense for natural enemies? Agric. Ecosyst. Environ. 194, 48-57.

Rainio, J., Niemelä, J., 2003. Ground beetles (Coleoptera: Carabidae) as bioindicators. Biodivers. Conserv. 12, 487-506.

Ramonet, Y., Giteau, J.-L., Tersiguel, E., Martel, G., 2014. Le choix des cultures dans les exploitations porcines en Bretagne. Innov. Agron. 39, 43-53.

Reganold, J.P., Jackson-Smith, D., Batie, S.S., Harwood, R.R., Kornegay, J.L., Bucks, D., Flora, C.B., Hanson, J.C., Jury, W.A., Meyer, D., others, 2011. Transforming US agriculture. Science 332, 670-671.

Ricketts, T.H., 2001. The matrix matters: effective isolation in fragmented landscapes. Am. Nat. 157, 87-99.

Roche, B., Amiotte, C., Boussard, H., Joannon, A., Martel, G., 2013. Crop acreage allocation decisions on intensive mixed crop-livestock farms. 64th Annual Meeting of the European Federation of Animal Science, Nantes, France.

Rotz, C., Mertens, D., Buckmaster, D., Allen, M., Harrison, J., 1999. A dairy herd model for use in whole farm simulations. J. Dairy Sci. 82, 2826-2840.

Rounsevell, M.D.A., Annetts, J.E., Audsley, E., Mayr, T., Reginster, I., 2003. Modelling the spatial distribution of agricultural land use at the regional scale. Agric. Ecosyst. Environ. 95, 465479.

Schils, R.L.M., Olesen, J.E., del Prado, A., Soussana, J.F., 2007. A review of farm level modelling approaches for mitigating greenhouse gas emissions from ruminant livestock systems. Livest. Sci. 112, 240-251. doi:10.1016/j.livsci.2007.09.005

Souchère, V., Millair, L., Echeverria, J., Bousquet, F., Le Page, C., Etienne, M., 2010. Coconstructing with stakeholders a role-playing game to initiate collective management of erosive runoff risks at the watershed scale. Environ. Model. Softw. 25, 1359-1370. doi:10.1016/j.envsoft.2009.03.002

Taylor, P.D., Fahrig, L., Henein, K., Merriam, G., 1993. Connectivity is a vital element of landscape structure. Oikos 68, 571-573. 
Tersiguel, E., Ramonet, Y., Giteau, J.-L., Martel, G., 2012. Déterminants du choix de l'assolement par les éleveurs de porcs en Bretagne, 44ème Journées de la Recherche Porcine, IFIP Institut du Porc ; INRA, ACTN, pp. 103-108.

Thenail, C., Baudry, J., 2004. Variation of farm spatial land use pattern according to the structure of the hedgerow network (bocage) landscape: a case study in northeast Brittany. Agric. Ecosyst. Environ. 101, 53-72. doi:10.1016/S0167-8809(03)00199-3

Tilman, D., Fargione, J., Wolff, B., D’Antonio, C., Dobson, A., Howarth, R., Schindler, D., Schlesinger, W.H., Simberloff, D., Swackhamer, D., 2001. Forecasting agriculturally driven global environmental change. Science 292, 281-284.

Tscharntke, T., Klein, A.M., Kruess, A., Steffan-Dewenter, I., Thies, C., 2005. Landscape perspectives on agricultural intensification and biodiversity - ecosystem service management. Ecol. Lett. 8, 857-874. doi:10.1111/j.1461-0248.2005.00782.x

Varchola, J.M., Dunn, J.P., 1999. Changes in ground beetle (Coleoptera: Carabidae) assemblages in farming systems bordered by complex or simple roadside vegetation. Agric. Ecosyst. Environ. 73, 41-49.

Vasseur, C., Joannon, A., Aviron, S., Burel, F., Meynard, J.M., Baudry, J., 2013. The cropping systems mosaic: How does the hidden heterogeneity of agricultural landscapes drive arthropod populations? Agric. Ecosyst. Environ. 166, 3-14. doi:org/10.1016/j. 


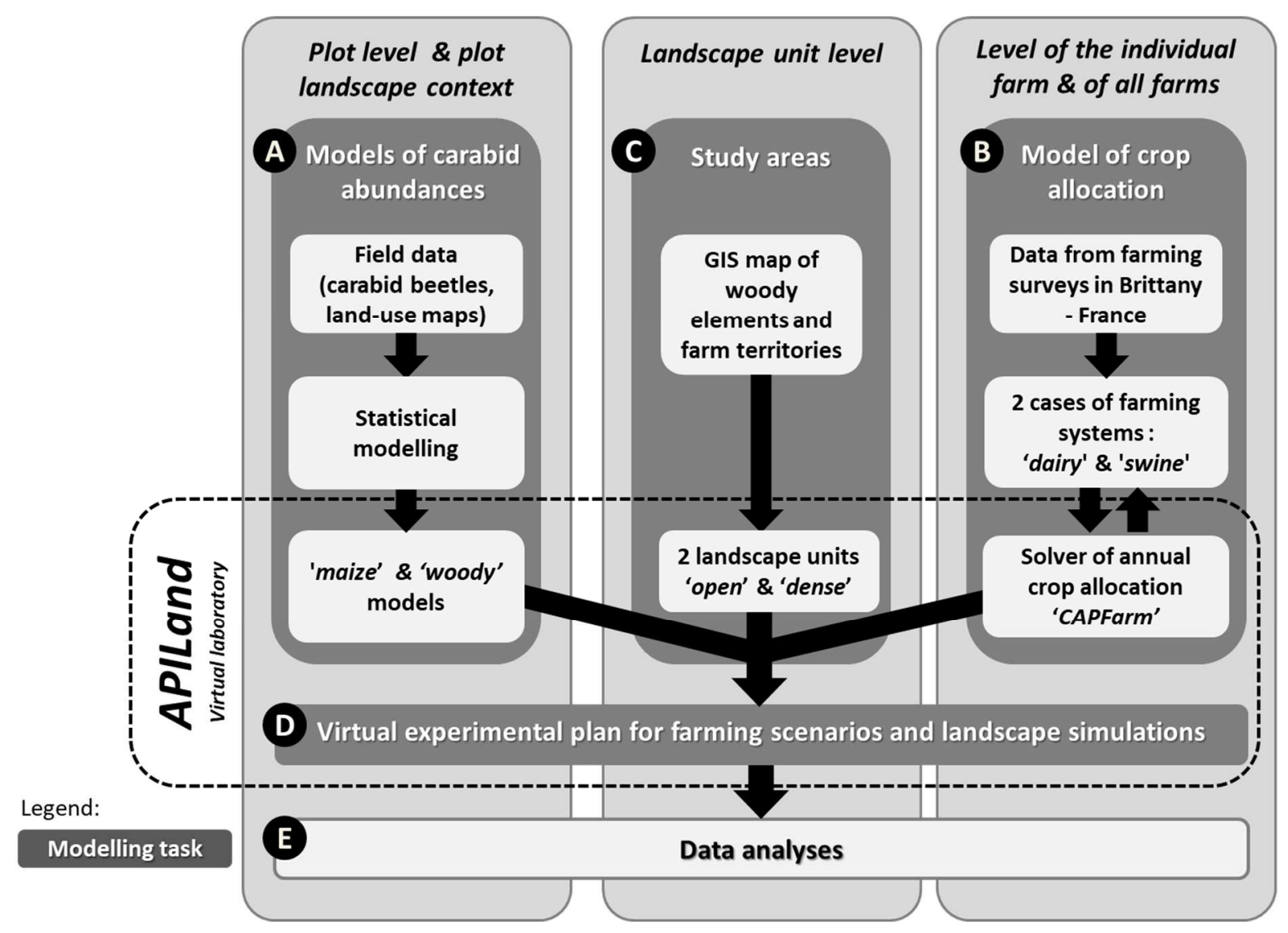

Figure 1: Overall view of the modelling approach used to simulate the diversity of agricultural

landscapes based on crop allocation decision rules at farm level and to estimate biodiversity according to landscape configuration. 

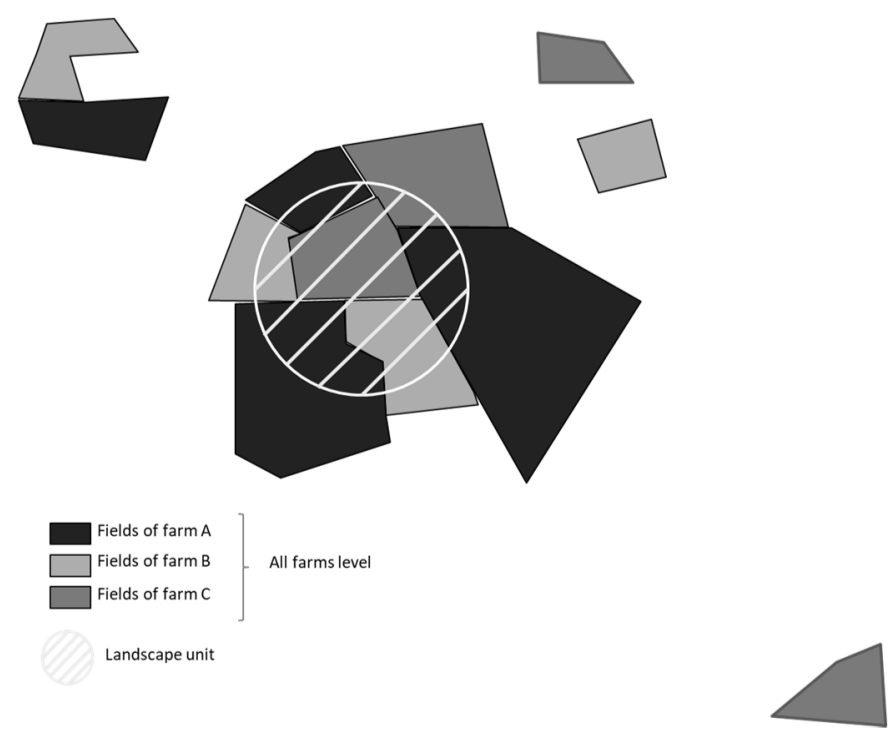

Figure 2: Landscape unit and farm / all farms levels considered in the modelling approach. 


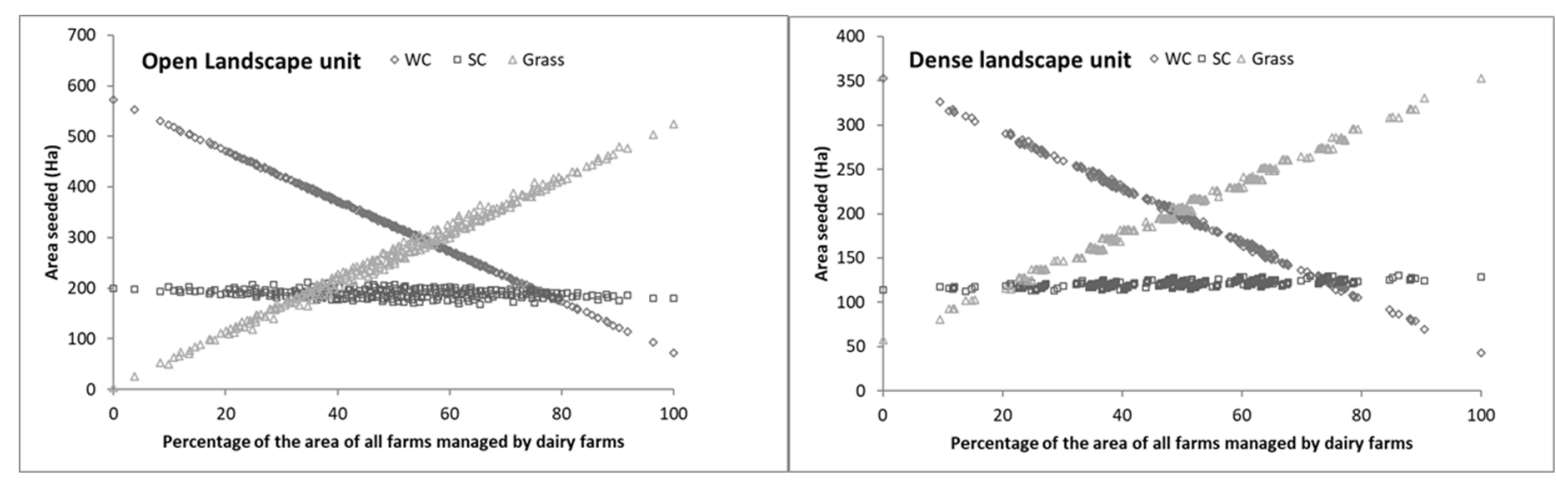

Figure 3: Averaged surface area (over the 1250 simulated landscapes x years) of winter crops (WC), spring crops (SC) and grassland (Grass) at the all farm level according to the percentage of the geographical area of all farms under dairy farming (left: open landscape unit, right: dense landscape unit. 


\section{Open Landscape unit}

Dense Landscape unit

a/ Area seeded in landscape unit according to the percentage of the area managed by dairy farm
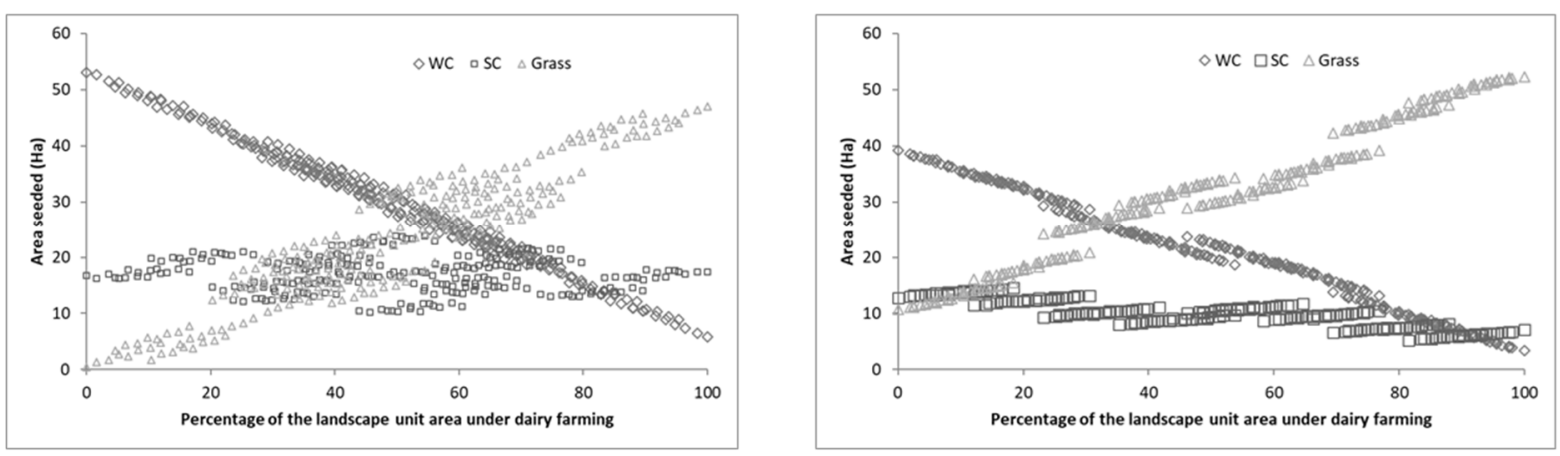

b/ Area seeded in landscape unit according to the number of dairy farm
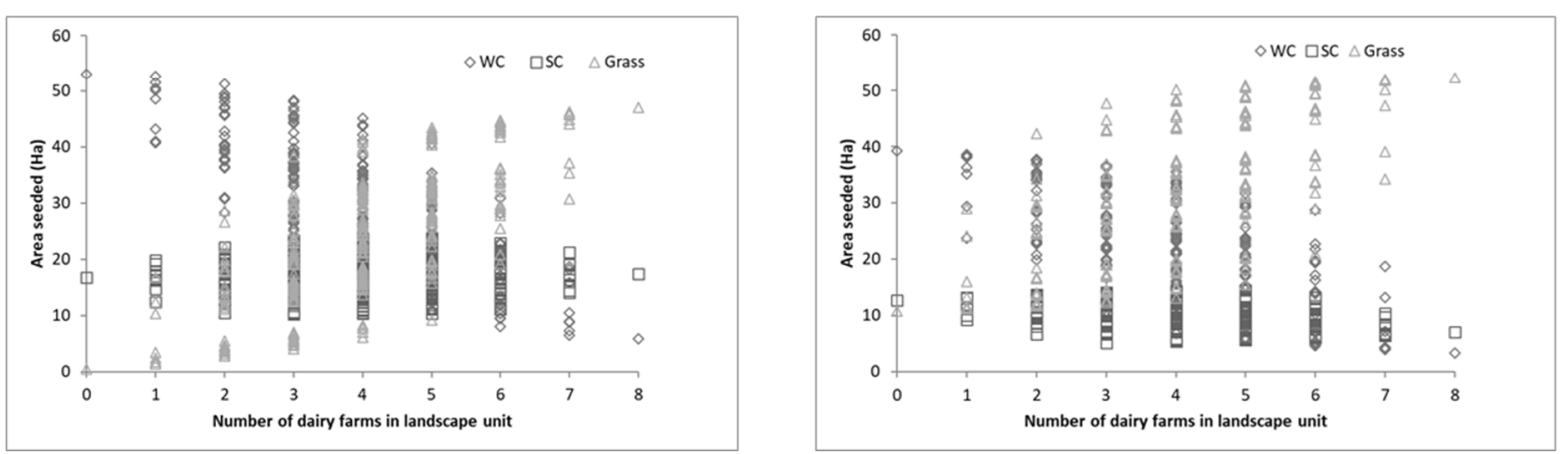

Figure 4: Average surface area (over the 1250 simulated landscapes x years) of winter crops (WC), spring crops (SC) and grassland (Grass) at the landscape unit level according to (a) the percentage of area under dairy farming and (b) the number of dairy farms in the open and dense landscape units. 


\section{1) Predicted abundances according to number of dairy farms}

a) Woody species

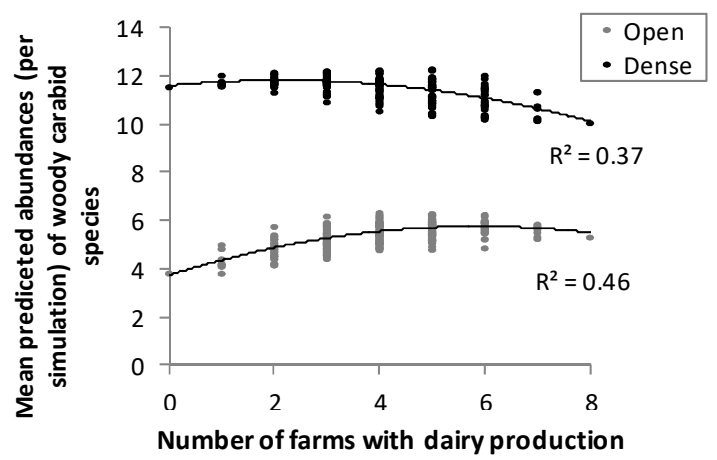

b) Maize species

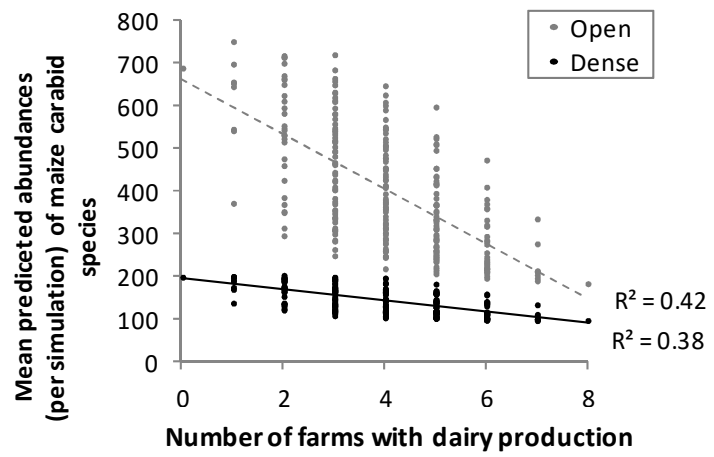

2) Predicted abundances according to surface area with dairy production

a) Woody species

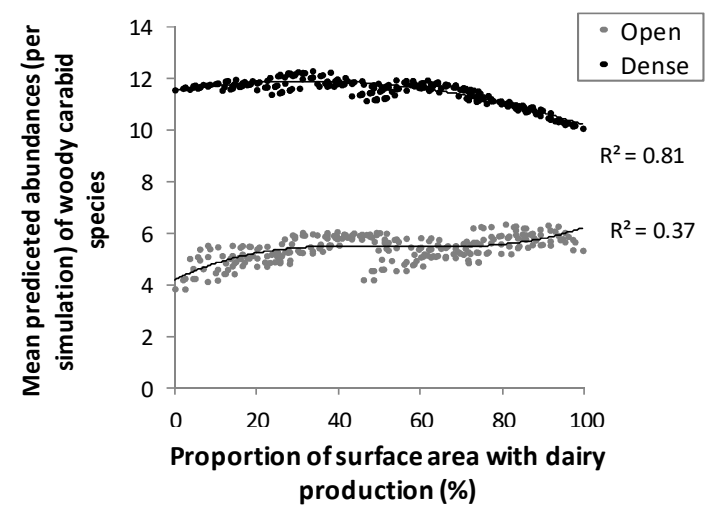

b) Maize species

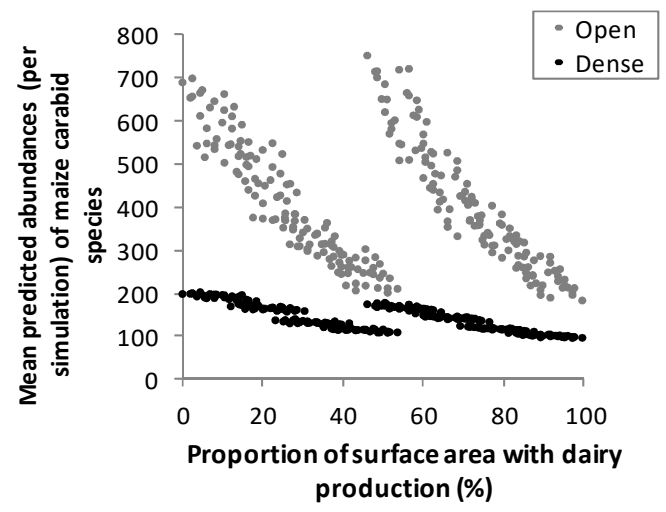

Figure 5: Predicted abundances of woody (a) and maize (b) species according to 1) the number of dairy farms and 2) the proportion of surface area under dairy farming in the dense and open landscape units. 
Table 1: Set of rules in Swine and Dairy farming systems for each crop.

\begin{tabular}{|c|c|c|c|c|c|c|c|c|c|c|c|c|}
\hline & Group & Crop & Code & $\begin{array}{l}\text { Allowed } \\
\text { previous } \\
\text { crop }\end{array}$ & Field size & $\begin{array}{l}\text { Min total } \\
\text { area }\end{array}$ & $\begin{array}{l}\text { min } \\
\text { return } \\
\text { time }\end{array}$ & $\begin{array}{l}\max \\
\text { rep. }\end{array}$ & $\begin{array}{l}\min \\
\text { dur. }\end{array}$ & $\begin{array}{l}\max \\
\text { dur. }\end{array}$ & $\begin{array}{c}\text { never } \\
\text { on }\end{array}$ & $\begin{array}{l}\text { Distance } \\
\text { from } \\
\text { farm's } \\
\text { head }\end{array}$ \\
\hline \multirow{5}{*}{ SFS } & & Maïze-Corn & $\mathrm{MC}$ & WH-BA & $>0.5 \mathrm{ha}$ & $\begin{array}{l}\max (5 \mathrm{ha} ; \\
5 \% \text { UAA) }\end{array}$ & 2 & 0 & - & 1 & - & - \\
\hline & & Wheat & WH & MC-RA & $>0.5 \mathrm{ha}$ & $\begin{array}{l}\max (5 \mathrm{ha} ; \\
10 \% \text { UAA) }\end{array}$ & 2 & 0 & - & 1 & - & - \\
\hline & & Barley & BA & WH & $>0.5 \mathrm{ha}$ & $\begin{array}{l}\max (5 \mathrm{ha} ; \\
5 \% \text { UAA) }\end{array}$ & 3 & 0 & - & 1 & - & - \\
\hline & & $\begin{array}{l}\text { Rape oil } \\
\text { seed }\end{array}$ & RA & WH-BA & $>0.5 \mathrm{ha}$ & $\begin{array}{l}\max (5 \mathrm{ha} ; \\
10 \% \text { UAA) }\end{array}$ & 3 & 0 & - & 1 & $\begin{array}{l}\text { Drained } \\
\text { plot }\end{array}$ & - \\
\hline & & $\begin{array}{l}\text { Permanent } \\
\text { Grassland }\end{array}$ & PG & PG & $<0.5 \mathrm{ha}$ & - & - & - & - & - & - & - \\
\hline \multirow{9}{*}{ DFS } & Maize & - & MA & - & $>0.5 \mathrm{ha}$ & $30 \%$ UAA & - & - & - & - & - & - \\
\hline & Maize & Maize-corn & $\mathrm{MC}$ & $\begin{array}{l}\text { LO-PA-MA- } \\
\text { WH-LU }\end{array}$ & - & - & - & 3 & - & 1 & - & $>400 \mathrm{~m}$ \\
\hline & Maize & $\begin{array}{l}\text { Maize- } \\
\text { Silage }\end{array}$ & MS & $\begin{array}{l}\text { LO-PA-MA- } \\
\text { WH-LU }\end{array}$ & - & - & - & 1 & - & 1 & - & $<400 \mathrm{~m}$ \\
\hline & Weed & - & WE & - & - & $33 \%$ UAA & - & - & - & - & - & - \\
\hline & Weed & Lolium & $\mathrm{LO}$ & MA-WH & $>0.5 \mathrm{ha}$ & - & - & 0 & 5 & 7 & - & $<5000 \mathrm{~m}$ \\
\hline & Weed & Pasture & PA & MA & $>0.5 \mathrm{ha}$ & $16,5 \%$ UAA & 2 & 0 & 5 & 10 & - & $<400 \mathrm{~m}$ \\
\hline & Weed & $\begin{array}{l}\text { Permanent } \\
\text { Grassland }\end{array}$ & PG & PG & $<0.5 \mathrm{ha}$ & - & - & - & - & - & - & - \\
\hline & - & Wheat & WH & MA-LU & $>0.5 \mathrm{ha}$ & $\begin{array}{l}\max (2 \mathrm{ha} ; \\
7 \% \text { UAA })\end{array}$ & - & - & - & 1 & - & - \\
\hline & - & Lucerne & LU & WH & $>0.5 \mathrm{ha}$ & $\begin{array}{l}\max (2 \mathrm{ha} ; \\
5 \% \text { UAA) }\end{array}$ & 8 & - & 3 & 4 & - & $>400 \mathrm{~m}$ \\
\hline
\end{tabular}

SFS: Swine farming system; DFS: Dairy farming system; UAA: Usable Agricultural Area; Return time is the number of years to wait between two sowings of the same crop on a same field; Max rep: Maximum number of successive seeding of a same crop on the same field; min dur. and max dur.: Minimum and maximum duration of crop. 
Table 2: Contribution of farms to the variation in maize carabid abundances in both landscape units and main characteristics of farms.

\begin{tabular}{|c|c|c|c|c|c|c|c|c|c|c|c|}
\hline $\begin{array}{l}\text { Landscape } \\
\text { unit }\end{array}$ & Farm & $\mathrm{FC}$ & UAA-S (ha) & $\mathrm{FI}(\mathrm{m})$ & $\mathrm{VI}(\mathrm{m})$ & VI-IN (m) & Min (ha) & p20 (ha) & Mean (ha) & p80 (ha) & Max (ha) \\
\hline \multirow{8}{*}{ Dense } & F6 & 0.0 & 1.5 & 605 & 0 & 0 & 0.0 & 0.0 & 0.7 & 1.5 & 1.5 \\
\hline & $\mathrm{F} 8$ & 1.2 & $1.6^{-}$ & $557^{-}$ & 134 & 0 & 0.0 & 0.0 & 0.4 & 1.2 & 1.2 \\
\hline & $\mathrm{F} 1$ & 1.4 & 1.2 & 514 & $99^{-}$ & 0 & 0.0 & 0.0 & 0.5 & 0.9 & 0.9 \\
\hline & $\mathrm{F} 4$ & 4.9 & 5.0 & 2232 & 561 & 0 & 0.0 & 1.5 & 2.5 & 3.4 & 4.7 \\
\hline & $\mathrm{F} 2$ & 5.5 & 2.3 & 928 & 275 & $185^{\circ}$ & 0.0 & 0.0 & 0.8 & 1.2 & 1.7 \\
\hline & F7 & 18.9 & 29.0 & 9887 & 731 & 282 & 9.1 & 13.9 & 15.9 & 17.8 & 22.2 \\
\hline & $\mathrm{F} 5$ & 20.9 & 7.6 & $2697^{-}$ & 676 & 353 & 2.0 & 3.9 & 4.4 & 5.1 & 5.6 \\
\hline & $\mathrm{F} 3$ & 50.4 & 14.6 & $3928^{-}$ & 1579 & 936 & 7.7 & 10.5 & $11.4^{\circ}$ & 12.4 & 14.0 \\
\hline \multirow{8}{*}{ Open } & O8 & 0.1 & 7.3 & 618 & 713 & 0 & 0.0 & 0.0 & 1.3 & 0.4 & 7.3 \\
\hline & 07 & 14.1 & 3.2 & 36 & 895 & 403 & 0.0 & 1.3 & 2.1 & 3.2 & 3.2 \\
\hline & $\mathrm{O} 3$ & 16.2 & 1.2 & 297 & 222 & 0 & 0.0 & 0.3 & 0.8 & 1.2 & 1.2 \\
\hline & 06 & 16.4 & 2.5 & 305 & 345 & 0 & 0.0 & 0.1 & 1.3 & 2.5 & 2.5 \\
\hline & 05 & 42.2 & 4.7 & 301 & 797 & 318 & 0.0 & 0.7 & 2.1 & 4.0 & 4.7 \\
\hline & $\mathrm{O} 1$ & 72.7 & 14.3 & 1317 & $1660^{\circ}$ & $602^{-}$ & 0.0 & 4.4 & 10.1 & 12.8 & 13.9 \\
\hline & $\mathrm{O} 4$ & 122.9 & 20.5 & $2884^{-}$ & 2089 & $739^{\circ}$ & 0.9 & 7.0 & 9.8 & 12.6 & $20.5^{-}$ \\
\hline & $\mathrm{O} 2$ & 230.1 & 16.6 & $961^{-}$ & 1675 & 721 & 5.5 & 13.4 & $14.9^{-}$ & 16.6 & 16.6 \\
\hline
\end{tabular}

FC: farm contribution to the variation in maize carabid abundances - UAA-S: farm's area within the landscape unit - Fl: length of fixed edge (one of the fields along the edge has a fixed land use in all simulations, eg. permanent grassland, wood or hedgerow) - VI: length of variable edges (both fields over the edge can have different covers according the years, eg. crops, temporary grasslands and lucerne) - VI-IN: variable edge length between two fields of the farm - Next 5 variables describes grassland area in the farm in all years simulated (min, average, max and $20 / 80$ percentiles). 
Table 3: Correlations of farm contribution to variation of maize carabid beetles with farm characteristics: only correlation with a p-value lower to 0.01 in one of the landscape unit are listed (D: dense landscape unit - O: Open landscape unit)

\begin{tabular}{|c|c|c|c|c|}
\hline \multirow{2}{*}{ Variables } & \multicolumn{2}{|c|}{$\mathrm{D}$} & \multicolumn{2}{|c|}{$\mathrm{O}$} \\
\hline & Spearman coefficient & P-value & Spearman coefficient & P-Value \\
\hline VI & 0.93 & 0.002 & $n s$ & $n s$ \\
\hline VI - IN & 0.94 & 0.001 & 0.78 & 0.022 \\
\hline Average - p20 & 0.8 & 0.017 & 0.85 & 0.008 \\
\hline Average - mean & 0.78 & 0.022 & 0.84 & 0.001 \\
\hline Average - p80 & $n s$ & $n s$ & 0.92 & 0.001 \\
\hline
\end{tabular}

$\mathrm{VI}$ : length of variable edges (both fields over the edge can have different covers according to the years, eg.

crops, temporary grasslands and lucerne) - VI-IN: variable edge length between two fields of the farm Average p20 / mean / p80: average value of 20th percentile, mean and 80th percentile of grassland area 